\title{
Branding of Purwakarta Regency through Gempungan di Buruan Urang Lembur in Health Services
}

\author{
Moh Faidol Juddi ${ }^{1, *}$ Susie Perbawasari ${ }^{2,}$ Susanne Dida ${ }^{3,}$ Aaat Ruchiat Nugraha ${ }^{4}$ \\ ${ }^{1}$ Universitas Padjadjaran \\ "Corresponding author. Email: juddisampoerna@gmail.com
}

\begin{abstract}
The branding of the Purwakarta Regency Government with the local wisdom of Sundanese culture through Gempungan di Buruan Urang Lembur activity has succeeded in gaining an appreciation by receiving the ISO 9001: 2008 certificate and Metamorphosis iNews Indonesia Award 2017 in the field of public services and health services. This success cannot be separated from the consistency of the Purwakarta Regency Government in presenting public services directly to all Purwakarta residents in all villages for more than two periods of government. Therefore, this study more deeply examines the implementation of Gempungan as local wisdom of the Purwakarta Regency Government and its provision of health services to the Purwakarata community with a qualitative descriptive method. The results show that the Gempungan activities provided free and promotive health services. This activity was scheduled to occur at a specific location known by Purwakarta Regency residents. In addition to mass treatment, Gempungan also attempted to create a "KB [family planning services] Village" and "Jampis."
\end{abstract}

Keywords: Gempungan, Branding, Local Wisdom

\section{INTRODUCTION}

The Regional Government (Pemda) of Purwakarta Regency is one of the districts in West Java that upholds the traditional values of the Sundanese culture in its government program. "Gempungan di Buruan Urang Lembur," which means the government continues to run in managing the village and arranging the city and glorifying the poor so they can live on equal terms. Gempungan is one of the implementations of Purwakarta Regency program contained in "Salapan Lengkah Ngawangun Nagri Raharja," or known as Nine steps in building Purwakarta prosperous. Gempungan is a safari activity that is "pick up the ball" by presenting services to the community directly (Herladianti, Damayanti, \& Prastowo, 2016). in terms of language, Gempungan means deliberation conducted before carrying out activities; the relationship between humans and society (Rita, 2019). Gempungan is an integrated program that provides services: population administration services and health, religious, and community activities. This safari activity is conducted in rotation in 192 villages in Purwakarta, twice a week on Wednesdays and Fridays.

Gempungan program is part of the "Purwakarta Istimewa" branding in improving education, health, and city quality services based on Sundanese local wisdom (Azhari \& Wahyuni, 2018). Through the city branding. The Purwakarta District Government strives to have a strong position regionally and globally. Branding efforts are conducted in a planned and sustainable manner to create mutual understanding between the government and the community. Branding through "Purwakarta Istimewa" is also an effort to maintain cooperation between the Purwakarta government and mass media and social media in the context of the accommodation needs of public information. Government institutions, in managing unique governance and development innovations, foster a distinct impression for the viewing audience. Purwakarta Regency has many historical, cultural, and regional characteristics. Development that promotes modernization while preserving traditional characteristics is a distinctive feature of Purwakarta.

The process of forming the Purwakarta Regency brand identity begins with anxiety because of its lessthan-optimal geographical location. The strong potential of indigenous Sundanese culture is one of the potentials that the Purwakarta government is attempting to develop to build a brand positioning based on a 9-step city branding program (Azhari \& Wahyuni, 2018). Changes to Purwakarta are increasingly advanced because of the 
development of public services, infrastructure, city governance, and restoration and development of natural and historical tourist destinations by highlighting the local wisdom of Sundanese culture. These efforts create a positive perception of Purwakarta from the community so that tourist visits increase (Gustini, Sanusi, \& Muchtar, 2018).

Leader factors and leadership involving ideology, innovation, assertiveness, and humility are the most prominent factors that determine the ability to implement good governance in Purwakarta (Febriantin, 2016). Dedi Mulyadi, as a Purwakarta regent, wants to make Purwakarta an independent area with a unique personality and character by raising local brands to revive Sundanese culture in all aspects of government and public services (Astuti, 2018).. Brand activation is performed through "Purwakarta Istimewa" to attract as many tourists and investors as possible. Although the "Istimewa" branding has not fully delivered maximum results in increasing the number of tourists and investors, the Purwakarta government has succeeded in presenting maximum public service and health through Gempungan. By contrast, the "One Roof Elementary School" program increasingly convinced the Purwakarta community about the performance of their government (Endang, 2019).

Innovations in city branding programs must be conducted continuously and measurably. Purwakarta branding through Gempungan services must continue to innovate the provision of public services because the true activity of branding is not merely "lip service" that emphasizes only "packaging" (Temporal, 2015). The public service was emphasized by the Purwakarta government through the Gempungan program by accommodating the aspirations of the Purwakarta community to determine the needs and problems of the community. Gempungan also provides services for the community in all villages on a regular basis (Herladianti, Damayanti, \& Prastowo, 2016). Technically, this activity is conducted from morning to evening by providing integrated services from various public service sectors organized by each Regional Organization (OPD) and are conducted massively at a certain time (Purwakartakab, 2017).

The Purwakarta government increased life expectancy by $69.56 \%$ in 2013 and $66.56 \%$ in 2007 because of Gempungan activity (Purwakarta, 2014).. The nutritional status data for children in Purwakarta in 2016 showed that out of 84,327 children aged younger than 5 years, $3.66 \%$ were undernourished, $0.56 \%$ is very less, $87.03 \%$ had good nutrition, and $1.45 \%$ has more than average nutrition (Moleong, 2013). Heart disease, hypertension, and diabetes mellitus have affected the Purwakarta community in the last 20 years (Haryanto, 2018). Cataract eye disease is also high. The Purwakarta
District Health Office reported 901 cases of catastrophe in 2016 (Rita, 2019).

"Purwakarta Istimewa" branding is a strategic effort of Purwakarta Regency to obtain a strong position locally and globally by strengthening local potential and resources through local branding by using the values of the Sundanese culture as a brand identity in the provision of services to the community through the Gempungan program. Through Gempungan, Purwakarta has obtained an ISO 9001: 2008 certificate and Metamorphosis iNews Indonesia Award 2017 in health services ( PPID, 2013). The Purwakarta government's innovations in providing health services with Sundanese cultural values are a notable topic for further study, especially the implementation of local culture in health services. Therefore, this study delves deeper into the implementation of Gempungan as a local branding of the Purwakarta Regency Government in their provision of health services to the community of Purwakarta.

\section{METHOD}

This study used a qualitative descriptive method with a post-positivistic paradigm. Qualitative indicates a research process that produces descriptive data in writing or verbally from people or behaviors directed at the individual frames as a whole by maintaining the integrity of the specifications (Bogdan \& Taylor, 1992). In the descriptive method, the data collected is in the form of words, sentences, and images, and not in the form of numbers, because of statistical processing (Moleong, 2013).

Data collection was conducted through in-depth interviews with the Health Office (Dinkes), the Purwakarta Regency population, and the Family Planning Matter Control Board (DPPKB) and direct observations, documentation, observations, websites, related social media, and the literature.

\section{RESULTS AND DISCUSSION}

\section{1. "Gempungan di Buruan Urang Lembur" Program in Health Services}

Health services provided by Gempungan activities were, for example, mass treatment, family planning services (KB), blood donation, mass circumcision, cataract eye surgery, and ultrasound for pregnant women. The Gempungan program is a Purwakarta Regency safari activity that provides public services directly to the community in cities and villages, for example, health services, population administration, and religious and community activities. This program has been active since 2008. In addition to public services, this activity provides a space for a direct dialogue or deliberation between the regent and the community, regarding the residents' concerns and needs. The Head of the Division (Kabid) of Health Services (Yankes) Purwakarta Health Office said: 
"Gempungan service is one of the programs in " Purwakarta Istimewa" which began in 2008. Along with its development, this program is in line with President Joko Widodo's programs call Nawacita, that community welfare starts from the outskirts of Hermawan, 2019"

"Puwakarta Istimewa" branding through the local branding Gempungan di Buran Urang Lembur holds meetings in yards or village fields and is one of the Purwakarta government's brand strategies, which "sells" the best possible service to the community. By presenting public services, including health services, the Purwakarta government has succeeded in building emotional relations between stakeholders and villagers. The vision of the Purwakarta Regency Government for integrated development is based on a combination of the basic values of land, water, air, and sun, as the basis for creation, a system of community life oriented to unity, and fulfillment and glory as a form of accountability for human representation on earth, which are Sundanese values (Nurhasanudin, 2019). One of the missions to realize that this vision is development based on local wisdom that has the value of religiosity and is oriented to the excellence of health services, education, social welfare, and equitable economic equality for the entire community.

\subsection{The Emotional Relationship Brand of The Gempungan In Health Services}

Branding is critical and performed by an organization to maintain a brand or service for the long term. A brand is known and felt and becomes part of people's lives. In building the emotional relationship of the brand with the audience, the organization must have means to convey the meaning of a service to have a soul (Dante, 2017). When building a brand's emotional relationship with its audience, several things should be considered; thus, the Purwakarta Regency Government should consider these aspects too. According to David A. Aaker (1995), a brand's emotional strategy is as follows (Aaker, 1995)

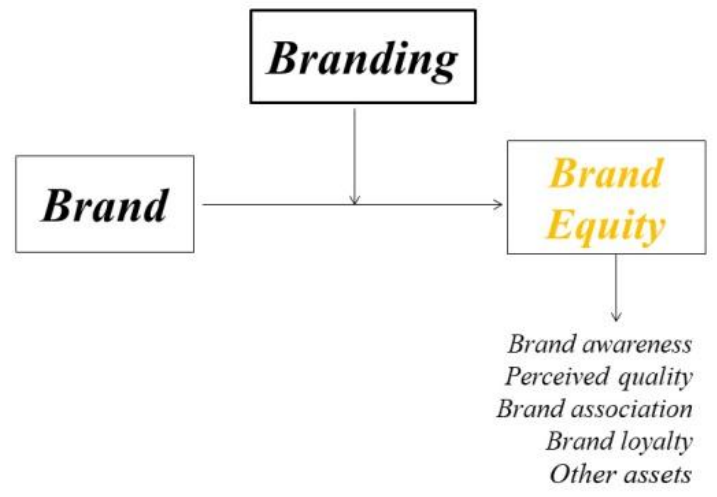

Figure 1 The brand's emotional strategy ladder (Source: Aaker, 1995; Rohendi, 2011)
Brand equity is the strength of a brand that can add or reduce the value of a brand, which is obtained from the response of customers or audiences to services provided. Brand equity has five categories: brand awareness, perceived quality, brand association, brand loyalty, and other assets.

\subsubsection{Brand Awareness}

Awareness appears for the first time through involvement in the form of experiments or deep relationships. People are more inclined to use services with names that they trust and are easily recognizable. The brand is identified from the name, picture, logo, and tagline used in program campaigns. As a brand identity, Gempungan is one unit with the "Purwakarta Istimewa" logo, which is a unified image of the Arjuna statue, jasmine buds, the Indung Karahayuan gate, and the "Purwakarta Istimewa" tagline, in brown and yellow. The selection of original Sundanese symbols in the logo represents Purwakarta as a typical Sundanese region.

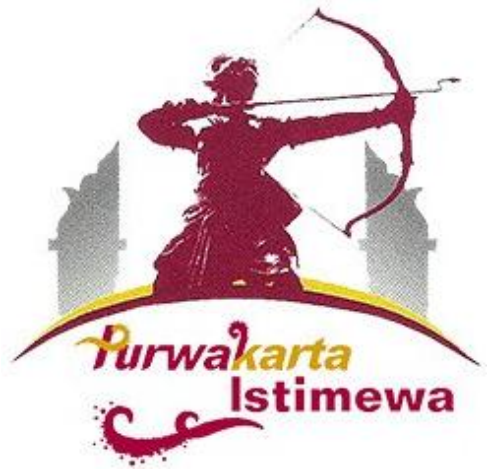

Figure 2 The brand logo of Purwakarta Istimewa (Source: Observation Results 2019)

The word Gempungan is native to Sundanese and means deliberation; the relationship between humans and society. Gempungan is commonly used by the Sundanese people to represent joint gathering activities in the field for the purpose of deliberation or to deliver announcements. Additional Sundanese language sentences "di Buruan Urang Lembur" behind the word "Gempungan" mean meeting in the yard of a village person. The choice of this word as a form of representation of public services that has become the local branding of the regency government of Purwakarta Regency is based on the local wisdom of Sundanese culture. Kabid Yankes Purwakarta Health Office said:

"The basis of health services in the Gempungan program is based on Sundanese culture ngariung baberangan or gathering together in solving problems with silih asih, silih asah and silih asuh in a religious and spiritual spirit in service (Hermawan, 2019).” 
The Gempungan mechanism for health services includes coordination with several Regional Device Organizations, which comprise the relevant office and sub-district or village agencies. Coordination meetings are held one week before the Gempungan activities are held (Yuli, 2019)

\section{Kabid Yankes Purwakarta Health Office said:}

“...Gempungan activities are prioritized for promotive and curative health activities, which require immediate service, served when the program takes place. people that require rehabilitative for further action, is referred to the hospital (Hermawan, 2019).

Health care services in the Gempungan program focus on services emphasized in health promotion activities and a series of medical activities that cure illnesses, reduce suffering due to illness, and control disease or disability so that patients' quality of life can be maintained. Referrals to hospitals are provided to community members who need rehabilitative actions that require further and serious handling.

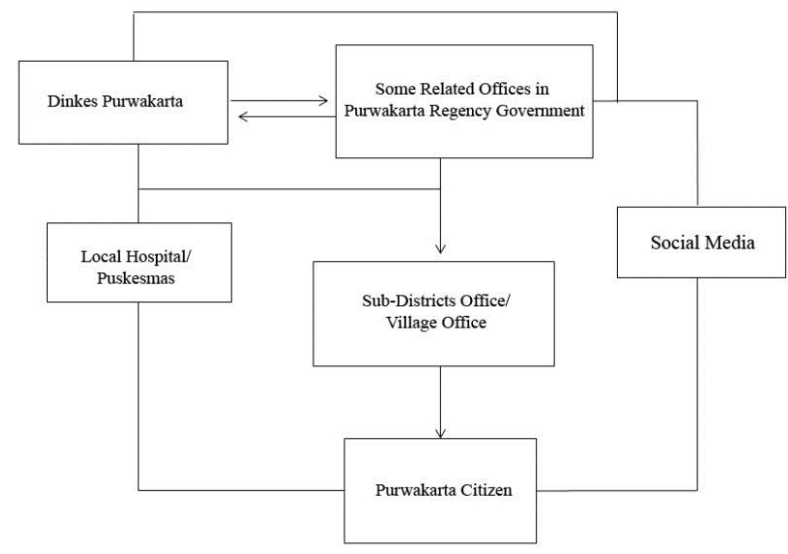

Figure 3 Mechanism and Communication Flow Gempungan for Health Service Program (Source: Research Results 2019).

\subsubsection{Perceived Quality}

Gempungan is a free public service for all Purwakarta residents, including the health services, that is, all health services, from mass treatment to cataract surgery, are all free. People obtain treatment at Gempungan by showing their National Identity Card (KTP) and Family Card (KK). In the early stages of the Gempungan program, services were exclusively for residents with low incomes. The program schedule runs three times per week and includes various types of health services. Yankes Purwakarta Health Office said:

"At the beginning when the Gempungan program was running, there was a requirement for a Certificate of Inability (SKTM) from the village office. However,
Bupati wants health services to be the right of all citizens. So, only KTP and KK are enough (Yuli, 2019)."

Perceived quality is based on the expectations and opinions of customers or public audiences and reflect the overall quality of services offered by brands through sight, sound, touch, and taste (Aaker, 1995). On-site health services in the Gempungan program provide health consulting services, health checks, and treatments. Notably, from 2008 to 2015 , health services included cataract eye surgery and circumcision (Yuli, 2019).

After evaluating the program, for several chronic diseases, such as heart disease, hypertension, and diabetes mellitus, Gempungan health services are limited to providing referrals to hospitals. This provision allows residents to skip the long BPJS queuing system at Pukesmas to receive care. One Purwakarta resident said :

\begin{abstract}
"Gempungan socialization and program in health services supported by social media have been very good. Some other supporting health programs, such as "Ambulance for Villages," are very helpful to the residents, even though they have not yet reached the whole area (Utami, 2019)."
\end{abstract}

Health services in Gempungan covered mass medication, KB services, blood donation, pregnancy ultrasound, and other services (e.g., mass circumcision and cataract eye surgery. However, since 2017 mass circumcision has not been conducted routinely. The Gempungan health service programs were evaluated regularly. Several health care services such as cataract eye surgery were not regular. For cataracts and several other serious diseases, Gempungan emphasized providing referrals for further action by the hospital. Notably, circumcisions were limited to an as-needed basis (Yuli, 2019).

\subsubsection{Brand Association}

A strong brand association can increase the success of a program by attracting new target audiences or embracing the current target audience, and the campaign will be more effective if the brand is known. A stable brand association eliminates the doubts of the target audience regarding brand service quality (Aaker, 1995). Most residents in Purwakarta already knew the term Gempungan because this program has been implemented for more than ten years. Gempungan activities provide easy access for the community to government services, ranging from administering $\mathrm{KK}$ and KTP to health services, without having to wait long lines. Gempungan activities have also become a means for citizens to convey concerns to the government directly. One of Purwakarta citizen said: 
“...Health services through Gempungan activities have been conducted very well by the government. The community does not need to bother queuing to the health center or hospital to get health services or just waiting in line for referrals. "Pick up the ball" service is very helpful for the Purwakarta society (Utami, 2019)."

The Purwakarta Regency Government through the Health Office and several related offices always strives to evaluate the service programs that have been provided. In addition, the government continues to update community services and targets. The government has proposed that public services should be permanent. In 2017, the Purwakarta Regency Government, through the health department and DPPKB, targeted the establishment of a "KB Village" to reduce population growth and build high resilience families (Endang, 2019).

The government's policies are based its belief that families are the primary educator of children, including the noble Sundanese cultural values of silih asih, silih asah and silih asuh. Thus, empowering KB Villages would create quality, happy, prosperous, independent, and resilient residents (Faridulihsan, 2019). In 2018, the DPPKB and the Health Office build $18 \mathrm{~KB}$ Villages in several areas in Purwakarta. In addition, the Health Office in collaboration with BPJS Health Purwakarta Office made an effort to "pick up the ball" at the Gempungan program by providing BPJS Health access services to residents who were poor and not covered by the BPJS central office.

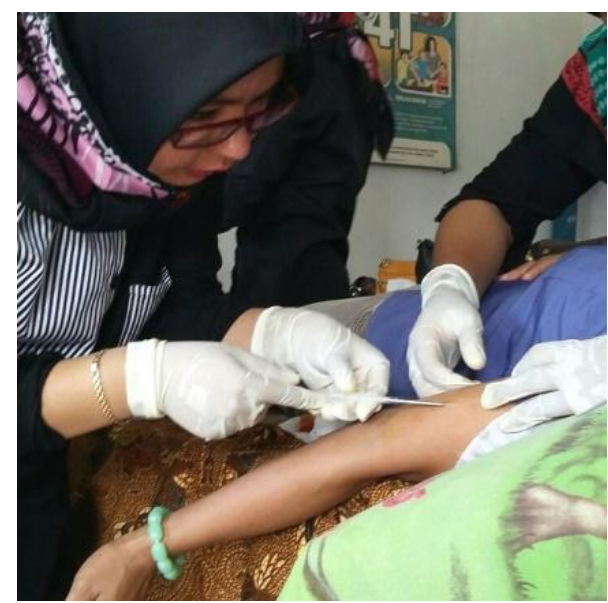

Figure 4 Installation of an IUD KB in Gempungan Activities (Source: Observation Results 2019).

Most BPJS Health participants are working citizenship as employees. The reason why many poor residents in Purwakarta have not registered to receive a Healthy Indonesia Card (KIS), health insurance from the central government, is the government's failure to provide adequate access to information and administration. The focus of the Gempungan service was access to BPJS for unregistered, poor residents. This effort was also to increase public enthusiasm for Gempungan activities (Yuli, 2019).

\subsubsection{Brand Loyalty}

Brand loyalty is a measure of the customer's relationship with a brand. Brand loyalty shows an attachment between the target audience and the brand that is characterized by repurchasing or re-requesting the service. When brand loyalty is strong, the organization does not need to make additional efforts and spend additional funds on campaigns for massive socialization (Aaker, 1995). Gempungan activities are routinely held twice per week on Wednesday and Friday. This activity had a definite location for all villages in Purwakarta. Socialization is conducted by local village officials if there are changes related to the Gempungan schedule and location. However, without direct socialization through the village apparatus, most citizens were consciously accessing Gempungan information updates through the Purwakarta district government's social media. The village apparatus functions as a confirmation and reminder (Yuli, 2019).

The community uses Gempungan activities for mass treatment services related to minor ailments, such as flu, cough, fever, and fatigue. in addition, elderly individuals use this activity for check-ups and health consultations, such as blood sugar and blood pressure checks. Mothers use this activity for family planning, IUD installation, and pregnancy checks through ultrasound. Health services in Gempungan are popular because they are free and close to home. In addition, users can avoid the long queue at the health center or hospital.

One Purwakarta citizen said:

"Facilitating community service, bringing services and government closer to the community throughout Purwakarta district. This benefit needs to be conveyed more deeply to the residents because some of them are still not too sure about the advantage of this activity (Utami, 2019)."

The Government of the Regent of Dedi Mulyadi has continued under Anne Ratna Mustika Mulyadi, and the Gempungan activities were held once per week on Wednesday. Health services focused on promotive and curative activities. For preventive activities, Gempungan only provided referrals to hospitals. Activities conducted routinely, such as mass circumcisions and cataract eye surgeries, were rarely performed. This activity was conducted contingent on instructions from the regent because the service was not routinely necessary. Nevertheless, no budget deduction was implemented related to health services by the Purwakarta Regency Government in order to continue 
the provision of effective and efficient services to the citizens of Purwakarta (Yuli, 2019).

\subsubsection{Other assets}

The other assets category in brand equity are things not included in the four categories of brand equity that have a significant impact on building brand equity (Aaker, 1995). The superior programs implemented the Purwakarta District Health Office were (1) Gempungan di Buruan Urang Lembur, (2) "Purwakarta Istimewa" Guarantee (Jampis), (3) an ambulance on call 24 hours per day seven days per week, and (4) mass circumcision services. In addition, the Health Office added Android-based health services, such as (1) Sampurasun Ambulance, (2) Sampurasun Doctor, and (3) Sampurasun midwife (SEMAR) (Endang, 2019).

"Jampis" is the cooperation between the Purwakarta Regency Government and the BPJS office to improve health services for the community. According to data from the Purwakarta District Health Office, in 2018, $83 \%$ of residents of Purwakarta were registered with BPJS Kesehatan, or 767,917 of 923,856 people (Nurhasanudin, 2019). That data is mixed data: individuals were covered by local governments, companies, independent policies. Through "Jampis," the Purwakarta Regency Government plans for KIS/BPJS to register up to $100 \%$ of Purwakarta residents.

Notably, regarding the district government's 24/7 ambulance service, the program did not cover the entire village (Rita, 2019). Village ambulances were assets owned by local villages, provided by the district government. In the future, each village will be given a card to access ambulance services. The Ambulance Village concept uses the philosophy babarengan dipiboga babarengan diperlakukeun, or joint property maintained together (Endang, 2019).

The superior service of the Purwakarta Regency Government is integrated into one Oga Lopian mobile application. The Ogan Lopian application was developed by the Purwakarta district government to connect, monitor, analyze, and control various resources within the city to increase efficiency and efficacy. This Android-based application is specifically for the local community of Purwakarta. Health services integrated into the Ogan Lopian application include SEMAR. The three services in this application provide services directly to the patient's location according to the needs of the community. The limited number of patients that visit the center for health services has made the Purwakarta Regency Government attempt as optimally as possible in terms of service. With the online health service feature, residents of Purwakarta Regency who cannot access health services can receive a visit from a doctor or midwife through the Ogan Lopian application (Purwakartakab, 2017).

The spirit of government service in the Purwakarta district through local wisdom is conducted by preserving and utilizing traditional methods of service and herbs. The district government does not prohibit and removes traditional practices that are unsafe and insecure, for example, the Peraji or birth healer. Most urban residents consider the practice of Peraji unsafe for mothers and children. However, in rural areas, this practice continues and is used by women giving birth. Efforts to synergize traditional culture with modern knowledge are conducted by the government by providing assistance and education for Peraji in practice by midwives (Endang, 2019).

\section{CONCLUSION}

The purpose of Gempungan di Burang Urang Lembur branding is more than brand recognition, the brand is also felt and becomes part of people's lives. Brand equity has five categories: brand awareness, perceived quality, brand association, brand loyalty, and other assets. With strong branding through public services, the Purwakarta district government strives to have a strong position, regionally and globally.

Brand awareness "Purwakarta Istimewa" can be related through Gempungan activities, which focus on safari activities that "pick up the ball" by presenting services to the community directly to all corners of Purwakarta through promotive and curative health activities. The implementation mechanism of health Gempungan includes coordination and socialization with several OPDs, comprising related offices and sub- 
districts or village officers. All health services, from mass medication to cataract surgery, are 11 free. The perceived quality of and Gempungan program's health services in the. The program consistently provides direct health consultations, health checks, and medication services. The socialization of the Gempungan program's health services was supported by social media and has been satisfactory.

Gempungan activities are one of the most anticipated programs of the Purwakarta Regency Government. Brand association is based on the government's efforts to update related services and goals of the community. The Purwakarta Regency Government, through the Health Office and DPPKB, is attempting to establish a "KB Village" to reduce the rate of population growth. In addition, the Health Office cooperates with the Purwakarta BPJS Health office to "pick up the ball" at the Gempungan program by providing BPJS Health access services for poor residents not covered by the central BPJS office.

Gempungan activities have been scheduled with a definite location for all villages in Purwakarta in rotation. Gempungan health services have been sought after by the community because the services are free and close to home. Brand loyalty is proven by the community routinely utilizing this activity for mass medication of minor ailments. Other assets involve Purwakarta District Health Office programs: Gempungan di Buruan Urang Lembur, "Purwakarta Istimewa" Guarantee (Jampis), an ambulance on call 24 hours per day seven days per week, and mass circumcision services. In addition, the Health Office also has an Android-based health service application "Ogan Lopian," which includes SEMAR. The spirit of government service in Purwakarta district is infused with local wisdom and conducted through the synergy of Peraji practices with assistance from and education for midwives.

\section{REFERENCES}

[1] Aaker, D. A. (1995). Building strong brands. New York: The Free Press.

[2] Astuti, D. R. (2018). The image of Sundanese culture city :The phenomenological study on public relations of local government in Purwakarta district. In International Conference on Media and Communication Studies (Vol. 260, pp. 267-270). Bandung: Atlantis Press.

[3] Azhari, A. B., \& Wahyuni, I. I. (2018). Analysis of the branding process of Purwakarta district. In $e$ Proceeding of Management (pp. 1225-1232). Bandung: Universitas Telkom.

[4] Bogdan, R., \& Taylor. (1992). Introduction to Qualitative Research Methods (Translation by Arief Rurchan). Surabaya: Usaha Nasional.
[5] Dante, V. (2017). Understanding the importance of branding for product survival. Rappler.Com. Retrieved from https://www.rappler.com/indonesia/gayahidup/185870-memahami-pentingnya-brandingbagi-kelangsungan-produk

[6] Dinas Kesehatan Purwakarta. (2014). Health profile of Purwakarta Regency in 2014. Purwakarta. Retrieved from http://www.depkes.go.id/resources/download/profil /PROFIL_KAB_KOTA_2014/3214_Jabar_Kab_P urwakarta_2014.pdf

[7] Febriantin, K. (2016). Leadership factors and leadership in governance in Purwakarta district for the period 2008-2015. Jurnal Politikom Indonesia, 1(2), 43-58. Retrieved from https://journal.unsika.ac.id/index.php/politikomind onesiana/article/view/617

[8] Gustini, Y., Sanusi, I., \& Muchtar, K. (2018). Government efforts in shaping the image of Purwakarta through local wisdom. Jurnal Ilmu Hubungan Masyarakat, 3(4), 97-114.

[9] Haryanto. (2018). These three diseases are mostly suffered by Purwakarta residents, this is the reason. Tribunnews.Com. Retrieved from http://jabar.tribunnews.com/2018/11/12/tigapenyakit-ini-paling-banyak-diderita-wargapurwakarta-ini-penyebabnya

[10] Herladianti, A., Damayanti, T., \& Prastowo, F. A. A. (2016). Imaging the regent of Purwakarta through Gempungan activities in Purwakarta district. Edutech, 15(2), 112-137.

[11] Hermawan, Endang. Personal Interview. May $20^{\text {th }}$, 2019. head of the community service section of the Purwakarta district health office . Purwakarta.

[12] Kusumaningtyas, A. (2016). City branding and public policy (Case study in Purwakarta district). Universitas Gajah Mada.

[13] Moleong, J. L. (2013). Qualitative research $m$ ethods. Bandung: PT Remaja Rosdaakarya.

[14] Mulyadi, D. (2018). Purwakarta in numbers. Purwakarta. Retrieved from https://purwakartakab.bps.go.id

[15] Nurhasanudin, D. (2019). Purwakarta Regency launches the Jampis recipient family. Ayopurwakarta.Com. Retrieved from http://www.ayopurwakarta.com/read/2019/03/13/2 331/pemkab-purwakarta-launching-keluargapenerima-jampis

[16] PPID, P. (2013). Chapter V: Vision, mission, goals and objectives (Amendment to Perda No. 15 of 2013 concerning RPJMD Purwakarta Regency in 2013 -2018). Purwakarta. Retrieved from http://ppid.purwakartakab.go.id/uploads/c75735a94 b3bdefb03126d8a678408d5.pdf

[17] Prayoga, F. (2017). Steady! Metamorphosis iNews 
Indonesia Award 2017, Dedi Mulyadi received an award in the field of IT-based health services. No Title. Okezone.Com.

[18] Purwakartakab.co.id. (2017). Health services: Purwakarta serves a soulful society. Retrieved February 6, 2019, from https://www.google.com/search?client=firefox-b$\mathrm{d} \& \mathrm{q}=$ ogan+lopian+release

[19] Rohendi. (2011). Political marketing communication pattern Regent Purwakarta period 2008-20I3 (Phenomenology Study of "Gempungan" Activities in Purwakarta Regency). Kom \& Realitas Sosial, 2(2), 1-15. Retrieved from http://jurnal.ubl.ac.id/index.php/JIK/article/view/37 2

[20] Temporal, P. (2015). Branding for the public sector: Creating, building and managing brand people will value (1st ed.). Sussex: John Wiley \&
Sons, Inc.

[21] Utami, Rita. Personal Interview. April 25 2019. House wife. Purwakarta.

[22] Wasesa, S. A. (2011). Politic branding and public relations. Jakarta: Gramedia Pustaka Utama.

[23] Winarsih, I. N. (2018). Stunting cases in Purwakarta are high, this is a feature of stunting. Republikas.Co.Id. Retrieved from https://gayahidup.republika.co.id/berita/gayahidup/info-sehat/pqlgsj459/kasus-emstuntingemdi-purwakarta-tinggi-ini-ciriciri-stunting

[24] Yanuariska, Y. Y., Sudaryat, Y., \& Isnendes, R. (2017). The tradition of copying in the life of the Sunda community (Structure and ethnagagogic study). Lokabasa, 8(2), 231-243.

[25] Yuli. Personal Interview. May 20 ${ }^{\text {th }}, 2019$. The Staff of the community service section of the Purwakarta district health office. Purwakarta. 